\title{
Fertilization packages increased growth and yield of Inpara 2 rice on tidal swampland of Aceh Jaya District
}

\author{
Idawanni ${ }^{*}$ Fenty Ferayanti, Basri A. Bakar, and M. Ismail \\ Asessment Institute for Agricultural Technology of Aceh Province, Jl. P. Nyak Makam No 27, \\ Lampieneung, Indonesia
}

\begin{abstract}
Tidal swampland is potential but negligible land characterized by poor soil fertility. The study aimed to determine the effect of fertilization packages on the growth and yield of Inpara 2 rice in the tidal field. This research was conducted on the tidal field of Mon Mata Village, Krueng Sabee Sub District, Aceh Jaya, from July to November 2018. The study was designed in a Randomized Block Design three treatments, and three plot replications of $10 \mathrm{~m} \times 10 \mathrm{~m}$. The treatments comprised of three fertilization packages, namely: Farmer's package A (Urea $100 \mathrm{~kg} \mathrm{ha}^{-1}+$ SP $3650 \mathrm{~kg} \mathrm{ha}^{-}$ ${ }^{1}$ ); Package soil nutrient status B (Urea $200 \mathrm{~kg} \mathrm{ha}^{-1}+$ SP36 $100 \mathrm{~kg} \mathrm{ha}^{-1}+$ $\mathrm{KCl} 50 \mathrm{~kg} \mathrm{ha}^{-1}$ ), and Recommended package C (Urea $200 \mathrm{~kg} \mathrm{ha}^{-1}+$ SP36 $100 \mathrm{~kg} \mathrm{ha}^{-1}+\mathrm{KCl} 100 \mathrm{~kg} \mathrm{ha}^{-1}+1000 \mathrm{~kg}$ dolomite ha $\left.{ }^{-1}\right)$. The experiment showed that all three fertilization packages significantly impacted plant height, panicle length, number of panicles per hill, grain per panicle, and grain yield. The recommended fertilization package $\mathrm{C}$ gave the highest yield (5.20 tha $\left.\mathrm{th}^{-1}\right)$, followed by Package B $\left(4.78 \mathrm{tha}^{-1}\right)$ and Package A (3.55 tha$\left.{ }^{1}\right)$. The research suggests that Inpara 2 rice and fertilizers, according to the recommendations, are needed to increase rice productivity in tidal fields.
\end{abstract}

\section{Introduction}

Agricultural development requires expanding potential land areas of farming areas, including marginal (suboptimal) land, such as swamps. In Indonesia, swamps are estimated to be 33.4 million ha, about $60 \%$ (20 million ha) of which are tidal swamps and another $40 \%$ (13.4 million ha) are non-tidal swamps [1]. Tidal land area in Indonesia is estimated to be 20.1 million ha, $20-50 \%$ of which has the potential for agricultural land [2]

Aceh Province has a tidal swamp area of 491 ha and 8,015 ha of lowland swamp. With this area, swamp rice is expected to contribute significant rice production to Aceh Province [3]. Swamplands have a unique character, namely the presence of standing water over a long period. The stagnant water is not an accumulation of tidal water still, it arrives from surface water runoff in the area and the surrounding area due to its lower topography. The productivity of food crops in the cleared swampland is currently relatively limited compared to productivity in irrigated land.

\footnotetext{
* Corresponding author: Idawanniismail@yahoo.com
} 
Utilization of swamps for agriculture is generally still low. It varies from one area to another, considering its success, which depends on climatic conditions (flood or drought), poor drainage, acid to very acidic soils, the content of N, P and K varies widely. Generally low to very low, and high pest and weed disturbances as well as socio-economic constraints that weaken the public's interest in developing swamplands. [4,5]

The development of tidal swamp farming is a strategic step in responding to the increasingly complex challenges of increasing agricultural production. With proper management through the correct application of science and technology, tidal land has a potential prospect to be developed into productive agricultural land, especially in preserving food self-sufficiency, diversifying production, increasing income, providing employment, and developing agribusiness and territory [6].

Swamp land is an alternative land that can be used for various agricultural production activities. Despite the many obstacles faced in making these lands productive, this land use has contributed to the national food security system. Currently, swamps are still very dependent on the generosity of nature in the management of agricultural cultivation. The main problem faced is submerged stress which limits the growth and production of rice plants.

Cultivating rice in swamps has a high risk do to the acidic, deficient nutrients, and iron (Fe). Iron poisoning and nutrient imbalance are major problems. Iron poisoning causes the productivity of swampy rice to be relatively low $\left(1-2 \mathrm{t} \mathrm{ha}^{-1}\right)$ or even non-productive. There are several ways to treat iron poisoning, including planting tolerant varieties and fertilizing them to improve nutrient balance. Efforts to increase rice production and productivity can be made by improving cultivation technology through fertilization based on nutrient status and plant needs. Fertilization technology is one of the determining factors to increase food production [7]. One of the efforts to increase fertilizer efficiency in swamps is applying of fertilizers according to the availability of nutrients in the soil, the varieties planted and rice planting system.

Jajar legowo planting system is easy in plant maintenance (fertilization, pest control) and causes higher rice yields [8]. increasing rice production with the row legowo planting system must be supported by appropriate fertilization technology [9]. In line with developments and technological advances in fertilization and changes in nutrient status in the soil, fertilization technology needs to be studied so that the dosage of fertilization becomes more efficient and precise. The study aimed to determine the effect of fertilization packages on the growth and yield of Inpara 2 rice in the tidal field

\section{Materials and methods}

This research was located on a tidal field in Monmata Village, Krueng Sabee District, Aceh Jaya Regency. The assessment was carried out from July - November 2018 according to the planting schedule of local farmers. It used a randomized block design (RBD), three replications, and a plot measuring $10 \mathrm{mx} 10 \mathrm{~m}$. Soil tillage was done by perfectly, plowed twice with a hand tractor and then leveled so that the soil is well muddy. Seedlings of superior Inpara 2 variety were carried out using wet seedbeds with a seed density of $25 \mathrm{~g} \mathrm{~m}^{-2}$. Seedlings are transplanted from the nursery when they are 15 days old. Rice planting used a 2: 1 legowo row system with a $20 \mathrm{~cm} \times 10 \mathrm{~cm}$ x $40 \mathrm{~cm}$ spacing with 3 seedlings hill ${ }^{-1}$.

The treatments consisted of three fertilization packages, namely: Farmer's Package A (Urea $100 \mathrm{~kg} \mathrm{ha}^{-1}+\mathrm{SP} 3650 \mathrm{~kg} \mathrm{ha}^{-1}$ ), Package soil nutrient status B (Urea $200 \mathrm{~kg} \mathrm{ha}^{-1}+$ SP36 $100 \mathrm{~kg} \mathrm{ha}^{-1}+\mathrm{KCl} 50 \mathrm{~kg} \mathrm{ha}^{-1}$ and Recommended package C (Urea $200 \mathrm{~kg} \mathrm{ha}^{-1}+\mathrm{SP} 36$ $100 \mathrm{~kg} \mathrm{ha}^{-1}+\mathrm{KCl} 100 \mathrm{~kg} \mathrm{ha}^{-1},+1000 \mathrm{~kg}$ dolomite ha ${ }^{-1}$ [10]. Urea was applied two times, namely $1 / 2$ at the age of 7-10 days after sowing (DAS), and $1 / 2$ at the age of 25-35 DAS 
while SP-36 and $\mathrm{KCl}$ were given two times, each $1 / 2$ dose at the time of planting, and 20 days after planting. Fertilizer was delivered by spreading it among the rows of plants.

The plant height measured from the soil surface to the highest leaf tips at the age of 30 , 60 and 90 days after planting (DAP), number of tillers counted at the age of 30,60 and 90 DAP, panicle length, number of filled grains per panicle, the total number of grains per panicle, weight of 1000 seeds and grain yield per ha. The collected data were analyzed statistically and to determine the effect of the treatment. The Duncan advanced test was used at the $5 \%$ level.

\section{Results and discussion}

\subsection{Preliminary soil analysis}

Based on the analysis of the chemical properties of the soil before treatment, the experimental land used showed very low soil fertility, acidic soil $\mathrm{pH}(\mathrm{pH} 4.62)$ with moderate Al-dd content (Table 1). Ca, Mg and K-dd were low, which indicated low nutrient availability.

Table 1. Results of soil analysis before activities in tidal fields, Aceh Jaya District

\begin{tabular}{|c|c|c|}
\hline Type of analysis & Score & Criteria \\
\hline pH H2O & 4.62 & Acidic \\
\hline C-Organic (\%) & 4.82 & high \\
\hline N-total (\%) & 0.35 & moderate \\
\hline P-available (ppm) & 13.2 & low \\
\hline K-dd (cmol (+) kg) & 0.30 & moderate \\
\hline Ca-dd (cmol (+)/ kg & 2.90 & low \\
\hline Mg-dd (cmol (+) $/ \mathrm{kg})$ & 1.70 & low \\
\hline CEC $(\mathrm{cmol}(+) \mathrm{kg})$ & 18.52 & moderate \\
\hline Al-dd (cmol (+)/ kg) & 1.30 & \\
\hline Texture & & \\
Sand (\%) & 40.20 & \\
Dust (\%) & 24.10 & \\
Clay (\%) & 33.80 & \\
\hline
\end{tabular}

Analyzed at the Soil and Plant Laboratory of Aceh Assessment Institute of Agricultural Technology

Like most acid soils, the main problem that must be overcome is to reduce the high soil acidity level [11]. So far, control of soil acidity was carried out by providing organic matter or agricultural lime and dolomite in every growing season. [12]. The swampland area was characterized by overflow typology B, which was only overflowed with water at a single tide [13].

\subsection{Plant growth}

The effect of fertilization packages on plant height showed that at the age of 30 DAP, the fertilization packages were not significantly different (Table 2). Compared to 60 DAP and 90 DAP, the plant height was significantly different between fertilization package treatments. Fertilization packages $\mathrm{B}$ and $\mathrm{C}$ provided better plant height growth compared to package $\mathrm{A}$. Higher $\mathrm{N}$ and $\mathrm{P}$ ingredient doses are thought to cause better plant growth. Plant height is used as one of the growth parameters in rice plants, but high plant height growth does not guarantee greater yields. Plant growth is also influenced by two critical factors, namely genetic factors and environmental factors. Plant height is influenced by genetic traits and environmental conditions for plant growth [14]. Genetic factors are related to the inheritance of the nature 
or behavior of the plant itself, while environmental factors are related to the ecological conditions in which the plant grows. Each plant variety has different abilities in terms of utilizing growth facilities and adaptation to the surrounding environment. Therefore, these conditions will affect crop yields [15]. Several rice varieties suitable for tidal field have been released, including the Inpara 2 [16].

Table 2. Effect of fertilization packages on plant height of Inpara 2 variety at the age of 30, 60, and 90 DAS in tidal land, Aceh Jaya District

\begin{tabular}{|c|c|c|c|}
\hline \multicolumn{4}{|c|}{ Plant height (cm) } \\
\hline Package & 30 DAP & 60 DAP & 90 DAP \\
\hline A & $41.00 \mathrm{a}$ & $80.30 \mathrm{~b}$ & $96.55 \mathrm{~b}$ \\
\hline $\mathrm{B}$ & $42.54 \mathrm{a}$ & $83.26 \mathrm{a}$ & $100.71 \mathrm{ab}$ \\
\hline $\mathrm{C}$ & $42.21 \mathrm{a}$ & $84.64 \mathrm{a}$ & $103.51 \mathrm{a}$ \\
\hline
\end{tabular}

Note: The numbers followed by the same letter show no significant difference (Duncan test 0.05 ).

Based on the results of variance, it was seen that the fertilization package affected the number of tillers. Table 3 shows that the number of tillers at 30 DAP was not significantly different between fertilization packages, but at the age of 60 and 90 DAP, the number of tillers at fertilization packages $\mathrm{B}$ and $\mathrm{C}$ gave the highest results significantly different from fertilization packages A. At the age of 90 DAP vegetative growth (formation of tillers) decreased since the plant had entered the generative phase. In this phase the photosynthates in the dry matter were mainly translocated to the plant's generative organs. In addition, there is competition within the clumps of the plant itself so that the less competitive seedlings do not develop or die. The results align with another study that, the increase in the number of tillers correlated with the number of productive tillers [17]. Some tillers die, and the number will decrease until they are reached at a fixed number condition.

Table 3. Effect of fertilization packages on the number of the Inpara 2 tillers at the age of 30, 60, and 90 days in tidal fields, Aceh Jaya District

\begin{tabular}{|c|c|c|c|}
\hline Package & $\begin{array}{c}\text { Number of tillers } \\
\text { 30 DAP }\end{array}$ & $\begin{array}{c}\text { Number of tillers } \\
\text { 60 DAP }\end{array}$ & $\begin{array}{c}\text { Number of productive tillers } \\
\text { 90 DAP }\end{array}$ \\
\hline $\mathrm{A}$ & $10.37 \mathrm{a}$ & $15.38 \mathrm{~b}$ & $11.52 \mathrm{~b}$ \\
\hline $\mathrm{B}$ & $10.28 \mathrm{a}$ & $17.41 \mathrm{a}$ & $13.0 \mathrm{a}$ \\
\hline $\mathrm{C}$ & $10.86 \mathrm{a}$ & $17.96 \mathrm{a}$ & $13.3 \mathrm{a}$ \\
\hline
\end{tabular}

Note: The numbers followed by the same letter show no significant differences (Duncan test 0.05 ).

Other factors that influence the formation of tillers are spacing, planting season, fertilizers and varieties. The wide spacing, supported by a suitable environment, including soil fertility, has led to more tillers in rice plants [18]. The number of productive tillers was influenced by NPK fertilization [19]. From the average number of tillers, it was known that without $\mathrm{N}$ fertilization, the number of tillers was reduced and significantly different from those fertilized by $\mathrm{N}$ further develop from rice tillers. The high productive tillers also have the potential to produce high production [20]. The number of productive tillers which later produced grain was influenced by the total number of tillers [21].

\subsection{Yield components}

The research showed that the fertilization package affected panicle length, filled grain per panicle and total grain per panicle. Table 4 showed that the highest panicle length, filled grain per panicle and spotted grain per panicle were found in fertilization packages $\mathrm{B}$ and $\mathrm{C}$, different from fertilization packages A. Due to various types and in relatively large quantities fertilization packages, it is concluded that the plants will not be able to produce the expected 
results without fertilizer [22]. N, P, and $\mathrm{K}$ nutrients are macro-nutrients needed for rice plants' growth. Therefore, efforts to increase rice production and productivity can be carried out through improvements in cultivation technology [23].

Increasing the dose of Urea fertilization turned out to have a different effect on the growth of rice plants. The higher dose of urea fertilizer tends to increase the stems and weight of 1000 grains of rice. Conversely, an increase in the dose of complete fertilizer (NPK) increased the number of productive tillers, panicle length and the number of filled grains. According to the opinion [24], the application of N, P, K fertilizers both single and compound can significantly increase the number, length, weight of panicles and productivity compared without NPK application.

Table 4. Effect of fertilization packages on the panicle length, filled grain per panicle and, total grain per panicle of Inpara 2 variety in tidal fields, Aceh Jaya District

\begin{tabular}{|c|c|c|c|}
\hline Package & $\begin{array}{c}\text { Panicle length } \\
\text { (cm) }\end{array}$ & $\begin{array}{c}\text { Filled grain per } \\
\text { panicle (seed) }\end{array}$ & $\begin{array}{c}\text { Total grain per } \\
\text { panicle (seed) }\end{array}$ \\
\hline $\mathrm{A}$ & $19.40 \mathrm{~b}$ & $95.17 \mathrm{~b}$ & $130.25 \mathrm{c}$ \\
\hline $\mathrm{B}$ & $22.10 \mathrm{a}$ & $114.5 \mathrm{a}$ & $147.12 \mathrm{~b}$ \\
\hline $\mathrm{C}$ & $22.78 \mathrm{a}$ & $122.10 \mathrm{a}$ & $155.21 \mathrm{a}$ \\
\hline
\end{tabular}

Note: The numbers followed by the same letter show no significant difference (Duncan test 0.05 ).

Panicle length and the number of grains per panicle tended to be the same if growing environmental conditions are relatively uniform. The length of the panicle will be related to the yield of rice plants where the longer the panicle is usually, the more significant the total amount of grain. It has been reported a trend of increasing grain yield in longer panicles [25]. The number of grains per panicle has a positive correlation with the number of filled grains and production. The higher the number of grains per panicle, the higher the chance of the variety. Filled grain is a yield component that determines production, if the filled grain is high then the yield will be high [26].

The results of variance also indicated that the fertilization package affected the weight of 1000 seeds. Table 5 showed that the highest weight of 1000 seeds was obtained in the $\mathrm{C}$ fertilizer package which was significantly different from the A fertilizer package. The difference in weight of the 1000 seeds produced was closely related to the ability of each variety to absorb available nutrients, especially $\mathrm{P}$. the absorption of different $\mathrm{P}$ affected the photosynthate produced by rice plants [27]. With the increase in nutrient uptake, the nutrient needs will be fulfilled, and the metabolism runs optimally, causing carbohydrates, proteins and starches not to be inhibited [28].

Based on the results of variance, it shows that the fertilization package affected the yield per hectare. Table 5 showed that fertilizer package $C$ gave the highest yield per hectare, which was not significantly different from package B but was substantially different from fertilizer package A.

Table 5. Effect of fertilizer packages on the weight of 1000 seeds and yield per hectare, the Inpara 2 variety in tidal field, Aceh Jaya District

\begin{tabular}{|c|c|c|}
\hline Package & Weight 1000 seeds (g) & Yield per hectare (ton) \\
\hline A & $24.90 \mathrm{a}$ & $3.55 \mathrm{~b}$ \\
\hline B & $25.00 \mathrm{a}$ & $4.78 \mathrm{a}$ \\
\hline C & $25.10 \mathrm{a}$ & $5.20 \mathrm{a}$ \\
\hline
\end{tabular}

Note: The numbers followed by the same letter show no significant difference (Duncan test 0.05 ).

Appropriate fertilization for rice plants can provide better results because cultivated plants generally require nutrients of various types. It was almost certain that without fertilizer, the plants cannot produce the expected results. Nutrients must be given completely $(\mathrm{N}, \mathrm{P}, \mathrm{K})$ 
and $\mathrm{Ca}$ since they are needed to grow rice plants [29]. Meanwhile, the increase in yield and yield components was due to the increased transfer of assimilates into the seeds [30]. Therefore, efforts to the increase rice production and productivity can be carried out through improvements in cultivation technology, including fertilization. The results showed that the fertilizer recommendation package produced by the IAARD was able to increase rice productivity when compared to the farmers' method. The research suggests a balance of fertilizer needs the rice plant and the nutrient status of the cultivated tidal swampland.

\section{Conclusion}

The three fertilization packages significantly affected rice plant growth and yield, where the recommended fertilization package improved plant growth and produced the highest yield $5.20 \mathrm{t} \mathrm{ha}^{-1}$. The application of technology using the new superior rice variety of Inpara 2 rice and the application of fertilizers according to the recommendations is needed to increase rice productivity in tidal fields.

\section{References}

1. B. Kustianto, Supartopo, Maulana, and H. Aris, Screening of swamp rice lines for iron poisoning in Tamanbogo. Proceedings of the Appreciation Seminar on Rice Research Results to Support P2BN. Book 2. The Center for Rice Research. Agricultural Research and Development Agency (2008).

2. D.A. Suriadikarta, and M.T. Sutriadi. Agricultural Research and Development 26, 3 (2007)

3. BPS, Tables of Harvested Area, Productivity, Production of Rice in All Provinces (2011).

4. Widjaja-Adhi, I.P.G. Nugroho, Didi Ardi and A.S. Karama, Tidal land resources, swamps and beaches: potential, limitations and uses. In S. Partohardjono and M.Syam (Eds), Integrated Development of Tidal and Lowland Agriculture, Minutes of the National Meeting of Tidal and Swamp Land Agricultural Development, Puslitbangtan Bogor (1992).

5. I.G. Ismail, T. Alihamsyah, I.P.G. W. Adhi, Suwarno, T. Herawati, R. Taher, and D.E. Sianturi, Sewindu (1985-1993) Agricultural Research in Swamplands, Contribution and Development Prospects, (Agricultural Research Projects, 1994)

6. Abdurachman and E.E. Ananto. The concept of sustainable agricultural development in swamps to support food security and agribusiness development, In National Seminar on Agricultural Research and Development in Swamplands. Bogor, 25-27 July 2000.

7. D.N. Kasniari, N.A.A. Supadma, Agritrop. 26, 4 (2007).

8. H. Nakano, I. Hattori, and S. Morita, Grassland Sci. 60, 1 (2014)

9. Husnain, D. Nursyamsi, and M. Syakir, Journal of Land Resources 10, 1 (2016)

10. Anonymous, Recommendations for N, P and K fertilization in site-specific lowland rice. Ministerial Regulation No. 40/Permentan/OT.140/4/2007 dated 11 April 2007. Agricultural Research and Development Agency. Agriculture department, (2007)

11. L. Irsal et al, Road Map for Research and Development of Dry Land, (Agricultural Research and Development Agency, Ministry of Agriculture. 2014)

12. I.G.P. Wigena, Andriati. Journal of Land Resources 10, 1 (2016).

13. A. Adimihardja, K. Sudarman, and D.A. Suriadikarta, Tidal land development: success and failure viewed from the physico-chemical aspect of tidal land, in Proceedings of the National Seminar on Research Results Supporting the Acceleration of Tidal Land Development. Balitbangtan, Puslitbangtan, Balittra. Banjarbaru, (1998) 
14. E. Sujitno, T. Fahmi and S. Teddy, J. Assessment and Development of Agricultural Technology 14, 1 (2011)

15. F. Yong, and H. Sigid, Adaptation Test for New Superior Varieties (VUB) of Swamp Rice and Paddy Rice as an Effort to Utilize Sub-Optimal Land in Tanjung Jabung Timur Regency, Jambi Province, in Proceedings of the National Seminar on Sub Optimal Land 20 - 21 October 2016, Palembang (2016)

16. Suwarno, T. Alihamsyah, I.G. Ismail. Optimization of Tidal Land Use with the Application of Integrated Farming System Technology, in National Seminar on Agricultural Research and Development in Swamplands, Cipayung, 25-27 July 2000, Book I. Puslitbangtan, Bogor (2000)

17. A.A. Muliasari, Optimization of spacing and seedling age in lowland rice (Oryza sativa L.), in Thesis, Faculty of Agriculture, Bogor Agricultural Institute (IPB, 2009)

18. H.R. Sugeng, Rice Cultivation, (Various Sciences, Semarang, 2003)

19. R.S. Simatupang, Nurita, R. Noor, Response of Rice Plants to N, P, and K Fertilization in Potential Land New Openings. In: Prayudi B, et al. (eds), Swampland Food Crop Management, in Proceedings of Optimizing the Utilization of Food Crops Research Results in Swamp Lands Towards Food Security, Farmers and Consumers Welfare, Banjarbaru, 4-5 July 2000 (2001)

20. Suparyono and A. Setyono, Overcoming Problems of Rice Cultivation (Self-Help Spreader, Jakarta, 1997)

21. H. Yetti, and Ardian, The effect of using spacing on the growth and production of lowland rice (Oryza sativa L) IR 42 variety using the SRI (System Of Rice Intensification) method (Sago IX, 2010)

22. D.J. Halliday, M.E. Trenkel, IFA World Fertilizer Use Manual, (Paris, International Fertilizer Industry Association, 1998)

23. Wasito, M. Sarwani, and E.E. Ananto, Food Crops Agricultural Research 29, 3 (2010)

24. J. Purnomo, Effect of Compound NPK fertilizer on Rice Yield of Ciherang Varieties and Chemical Properties of Bogor Inceptisol Soil, in Proceedings of the National Seminar and Dialogue on Agricultural Land Resources, Balittanah, Bogor (2008)

25. I. Khairullah, S. Subowo, and S. Sulaiman. Yield and phenotypic appearance of tidal fields in South Kalimantan, in Proceedings of the IV Congress and the National Symposium of Perhipi, The Role of Glorification in the Prosperity of the Nation, Perhipi Komda DIY and Fak. Gajah Mada University Agriculture (2001)

26. S. Yuniarti, S. Kurniawati, Community Bulletin 3, 2 (2013)

27. Warisno, Hybrid Corn, (Canisius. Yogyakarta, 1998)

28. S. Taufik, S. Baharom, R.Y. Xiao, International Journal of advanced Materials Research, 250-253 (2011)

29. I. Ar-Riza \& S. Saragih. (2001). Soil and nutrient management for rice cultivation in tidal swamps. In: Ar-Riza, I., T. Alihamsyah, M. Sarwani (eds.). Water and Soil Management in Tidal Lands. Research Institute for Swampland Food Crops, Banjarbaru. (2001).

30. M. Bovairi, A. Shokuhfar, and G.R. Abadouz, Research on Crop Ecophysiology, 11, 2 (2016) 